

\author{
Zhang Wenqiang ${ }^{1,2}$ \\ Shan Baoqing ${ }^{1}$ \\ Zhang Hong ${ }^{1}$ \\ Tang Wenzhong ${ }^{1}$ \\ ${ }^{1}$ State Key Laboratory on \\ Environmental Aquatic Chemistry, \\ Research Center for Eco- \\ Environmental Science, Chinese \\ Academy of Science, Beijing, P. R. \\ China \\ ${ }^{2}$ University of Chinese Academy of \\ Science, Beijing, P. R. China
}

\section{Research Article \\ Characteristics of Phosphorus Compounds and Their Effects in Sediments of an Eutrophic Chaohu Lake, China}

\begin{abstract}
Surface sediments and sediment cores in a shallow eutrophic lake, Chaohu Lake, were analyzed by ${ }^{31} \mathrm{P}-\mathrm{NMR}$ to reveal the phosphorus (P) species and their effects on upper water quality. Total $\mathrm{P}$ (TP) in the NaOH-EDTA extracts was dominated by inorganic phosphate $\left(\mathrm{P}_{\mathrm{i}}\right)$, with higher levels being observed in the heavily eutrophic western lake $(79.1 \pm 1.7 \%)$ than in the eastern lake $(68.1 \pm 2.4 \%)$. These findings were opposite to those for organic phosphorus $\left(\mathrm{P}_{\mathrm{o}}\right)$. $\mathrm{P}_{\mathrm{i}}$ (ortho-phosphate and pyrophosphate) and $\mathrm{P}_{\mathrm{o}}$ (phosphonates, ortho-phosphate monoesters and phospholipids, DNA) were detected in the NaOH-EDTA extracts of the sediments by ${ }^{31} \mathrm{P}-\mathrm{NMR}$. The majority of $\mathrm{P}_{\mathrm{o}}$ consisted of ortho-phosphate monoesters $(80.2 \pm 2.7 \%)$. For sediment cores, the contents of phospholipids and DNA declined more rapidly than that of ortho-phosphate monoesters and pyrophosphate as sediment depth increased, with these compounds primarily occurring in the top $10 \mathrm{~cm}$ of sediment. The positive relationship between $\mathrm{P}_{\mathrm{o}}$ in sediment and TP in the water showed that $\mathrm{P}_{\mathrm{o}}$ compounds in the sediment would be released to the water. These compounds of $P_{o}$ will be mineralized to $P_{i}$ and potentially bioavailable for recycling to surface water, supporting further growth of aquatic organisms and leading to algal blooms.
\end{abstract}

Keywords: Eutrophication; Nutrient sources; Organic phosphorus; ${ }^{31} \mathrm{P}-\mathrm{NMR}$; Water quality

Received: April 2, 2013; revised: April 21, 2014; accepted: June 3, 2014

DOI: $10.1002 /$ clen.201300254

\section{Introduction}

The release of phosphorus (P) from sediment is a vital nutrient source that will induce continuous eutrophication in lakes even if external inputs are reduced [1]. Sediment-basic $P$ recycling depends to a large extent on the forms of $\mathrm{P}$ in sediments [2]. Sediment $\mathrm{P}$ includes inorganic phosphorus $\left(\mathrm{P}_{\mathrm{i}}\right)$ and organic phosphorus $\left(\mathrm{P}_{\mathrm{o}}\right)$, and $\mathrm{P}_{\mathrm{o}}$ constitutes a major $\mathrm{P}$ fraction in some sediments. Indeed, $\mathrm{P}_{\mathrm{o}}$ accounts for about $87 \%$ [3], 40-90\% [4], and 10-70\% [5] of total phosphorus (TP) in swamp sediments, Everglades, and lake sediments, respectively. The components of $\mathrm{P}_{\mathrm{o}}$ have been shown to be much more bioavailable to aquatic organisms than previously assumed [6]. Specifically, $\mathrm{P}_{\mathrm{o}}$ constituents can be hydrolyzed to phosphate and provide bioavailable $\mathrm{P}$ under some conditions $[7,8]$. Stable $\mathrm{P}_{\mathrm{o}}$ (e.g., phosphonate) can also be utilized by plankton and lead to algal blooms $[9,10] . \mathrm{P}_{\mathrm{o}}$ is a key part of $\mathrm{P}$ recycling that provides a nutrient source for aquatic organisms. Transformation and releasing of $\mathrm{P}_{\mathrm{o}}$ in the sediment can accelerate eutrophication, especially in eutrophic lakes. Studies have focused on $P_{i}$ and its

Correspondence: Prof. B. Q. Shan, State Key Laboratory on Environmental Aquatic Chemistry, Research Center for EcoEnvironmental Science, Chinese Academy of Science, Beijing 100085, P. R. China

E-mail: bqshan@rcees.ac.cn

Abbreviations: NMR, nuclear magnetic resonance; OM, organic matter; $\mathbf{P}_{\mathbf{i}}$, inorganic phosphorus; $\mathbf{P}_{\mathrm{o}}$, organic phosphorus bioavailability [11], however, investigations of the species, concentrations, dynamics and effects of $\mathrm{P}_{\mathrm{o}}$ in sediment have been limited because of its complexity and limitations of analytical methods [12, 13].

Several analytical methods have been developed to elucidate $P_{o}$ compounds, and these were usually estimated from the difference between TP and $\mathrm{P}_{\mathrm{i}}$ or fractionation with different acids and alkalis [14-16]. Although these methods have provided usefully information pertaining to $\mathrm{P}$ biogeochemical cycling in aquatic environments, they have not yielded sufficient insight into identification of specific $\mathrm{P}$ compounds [17]. Phosphorus-31 NMR spectroscopy $\left({ }^{31} \mathrm{P}-\right.$ NMR) is a non-destructive, non-invasive technique for identifying chemical forms that has the advantage of enabling multiple $\mathrm{P}$ compounds to be characterized simultaneously with distinct binding properties [12]. Therefore, it is an ideal technique for use in analysis of $\mathrm{P}_{\mathrm{o}}$ species in marine or freshwater sediment [18]. Several $\mathrm{P}$ compounds have been detected by ${ }^{31} \mathrm{P}-\mathrm{NMR}$, including phosphonates, ortho-phosphate, ortho-phosphate monoesters, orthophosphate diesters, pyrophosphate, and polyphosphate [19]. ${ }^{31} \mathrm{P}$ NMR spectroscopy can provide detailed information pertaining to $P_{o}$ species and concentrations, which will contribute to $P_{o}$ transformation and recycling. Application of ${ }^{31} \mathrm{P}-\mathrm{NMR}$ for detection of $\mathrm{P}_{\mathrm{o}}$ has also been shown to be more accurate than molybdate colorimetry because labile $\mathrm{P}_{\mathrm{o}}$ compounds may be hydrolyzed with the addition of acid [20, 21].

Lake eutrophication is a serious environmental problem in China [22], especially in areas that are densely populated or in which 
industry-agriculture has developed, such as Taihu Lake, Chaohu Lake and Dianchi Lake [22-25]. Accordingly, lake eutrophication has increasingly become a threat to water quality, human health and social development in the last 30 years in China [26]. Since the 1990s, studies have mainly focused on concentration of TP and $\mathrm{P}_{\mathrm{i}}$ and their transformation by $\mathrm{P}$ fractionation. However, little is known about the species and dynamics of $\mathrm{P}_{\mathrm{o}}$ in the sediments of eutrophic lakes. In this study, the Chaohu Lake was selected as a typical lake for investigation of sediment $\mathrm{P}$ compounds. The specific objectives of this study were to detect the P compounds in surface sediment and sediment cores by ${ }^{31} \mathrm{P}$-NMR and study the relationship between $\mathrm{P}$ in sediment and water quality. This study provides useful information pertaining to the compounds and dynamics of $\mathrm{P}$ in eutrophic lakes and management of lake eutrophication.

\section{Materials and methods}

\subsection{Study area and sediment sampling}

The Chaohu Lake, which is located in Anhui Province, eastern China, is one of the five largest freshwater lakes in China. The lake sits along the left bank of the Yangtze River between $31^{\circ} 25^{\prime}-31^{\circ} 43^{\prime} \mathrm{N}$ and $117^{\circ} 17^{\prime}-117^{\circ} 52^{\prime} \mathrm{E}$. The Chaohu Lake is a shallow lake, with a surface area of $750 \mathrm{~km}^{2}$ and a mean depth of $3 \mathrm{~m}$. As the largest freshwater lake in Anhui province, the Chaohu Lake plays a vital role in shipping, fisheries, agricultural irrigation and a drinking-water source. The lake has undergone serious eutrophication because of the excessive input of nutrients [27]. The Chaohu Lake is divided into eastern and western parts by Laoshan (an island in the Chaohu Lake) and Zhongmiao (a town). Owing to differences in socioeconomic development and pollutant input, algal blooms have occurred with increasing frequency and intensity in the western lake, and eastern lake regions have much better water quality.

To select representative sites in the Chaohu Lake, ten sampling grids were set up in July 2011 according to previously reported lake survey guidelines [28]. Each sampling grid had one sampling point that was selected based on water quality. Sites 1-4 and 5-10 were located in the western and eastern lake, respectively. Sediment cores were collected using a gravity corer (Uwitec, Austria) with PVC sampling tubes (diameter $6.3 \mathrm{~cm}$ and length $60 \mathrm{~cm}$ ). Three surface $(2 \mathrm{~cm})$ sediment samples of each sites were collected (Fig. 1). Samples at the same site were pooled and homogenized to obtain a representative sample. Two sediment cores were sampled for sites 1 and 8 using a gravity core sampler, and sediment cores were then transected into $2 \mathrm{~cm}$ segments in sequence. All of the samples were collected in July of 2011 . The samples were freeze-dried under $-50^{\circ} \mathrm{C}$ by FD-1 freeze-dryers upon arrival in the laboratory. Dried samples were ground and sieved to pass through a 100-mesh sieve. Quartering of the samples was taken as the representative samples, and then the samples stored in sealing plastic bag and stored at room temperature until analysis.

\subsection{Analysis of sample properties}

$\mathrm{TP}$ in sediment was measured by treating the samples at $500^{\circ} \mathrm{C}(2 \mathrm{~h})$, followed by extraction with $1 \mathrm{M} \mathrm{HCl}(16 \mathrm{~h}) . \mathrm{P}_{\mathrm{i}}$ was extracted without combustion with $1 \mathrm{M} \mathrm{HCl}(16 \mathrm{~h})$. The $\mathrm{P}_{\mathrm{o}}$ concentrations in the sediments were calculated as the difference between TP and $P_{i}[14]$. Organic matter $(\mathrm{OM})$ in sediments was determined based on the loss on ignition after heating at $550^{\circ} \mathrm{C}$ for $4 \mathrm{~h} \mathrm{[29]}$. TP in the water was measured using the molybdenum blue method after the digestion by persulfate, and the quality control of the analysis were carried

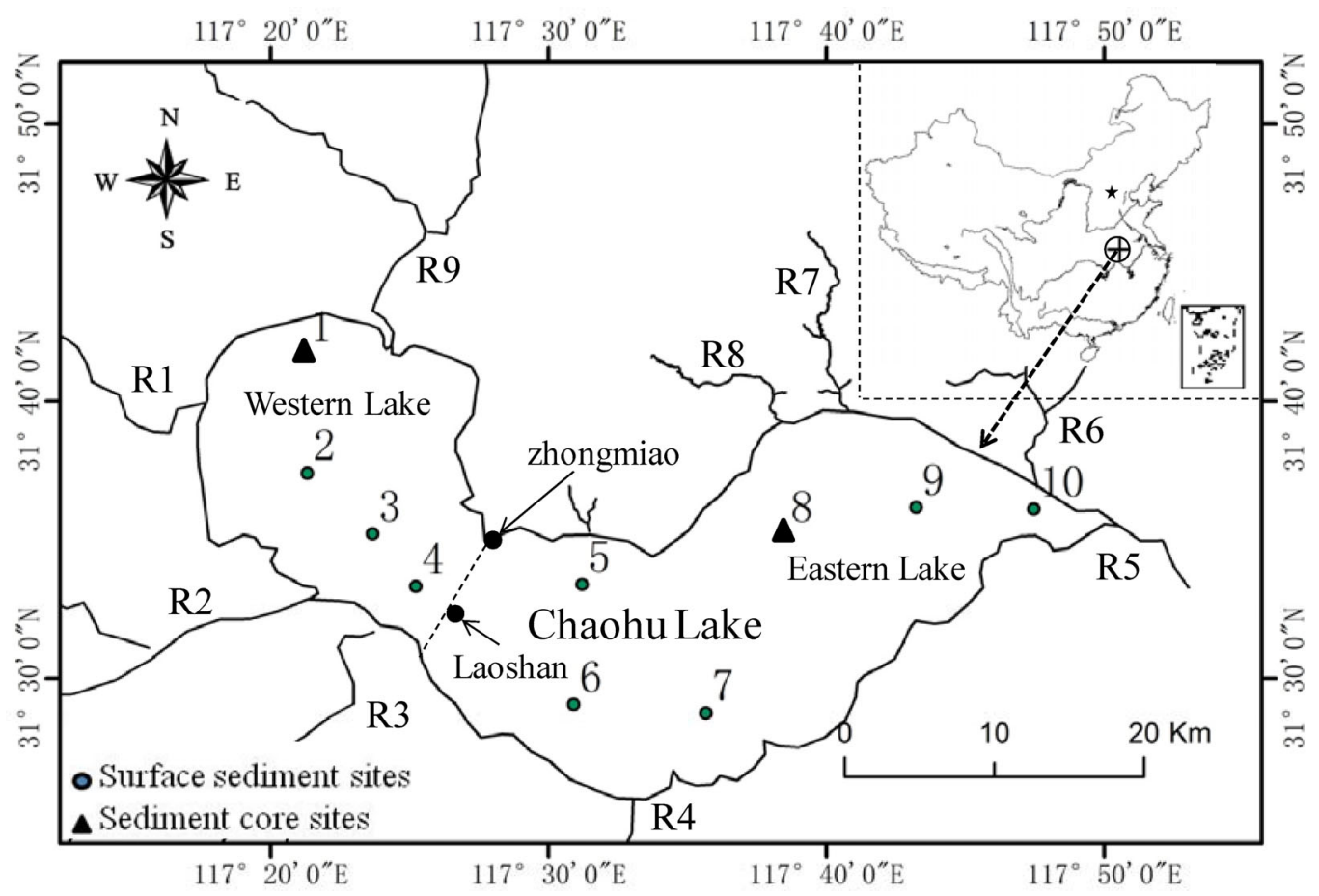

Figure 1. Location of sampling sites in the Chaohu Lake (R1, Pai River; R2, Fengle-hangbu River; R3, Baishishan River; R4, Mawei River; R5, Shuangqiao River; R6, Zhegao River; R7, Qiyang River; R8, Tongyang River; R9, Nanfei-dianbu River). 
out by deionized water [30]. The annual average TP in the water column was calculated for each site using monitoring data collected from 2009 to 2011. Three replicates were performed for each index, and the mean value was calculated.

\subsection{NaOH-EDTA extraction and ${ }^{31}$ P-NMR analysis}

Sediment samples $(3 \mathrm{~g})$ were extracted with $30 \mathrm{~mL}$ of a solution composed of $0.05 \mathrm{~mol} / \mathrm{L}$ EDTA and $0.25 \mathrm{~mol} / \mathrm{L} \mathrm{NaOH}$ for $16 \mathrm{~h}$ at room temperature [31, 32]. Aliquots of the EDTA/NaOH extracts were then used to analyze $\mathrm{P}_{\mathrm{i}}$ and TP using the molybdenum blue method before and after digestion with $\mathrm{K}_{2} \mathrm{~S}_{2} \mathrm{O}_{8}$, after which the $\mathrm{P}_{\mathrm{o}}$ was determined based on their difference. The remaining solution was frozen and lyophilized and then used for ${ }^{31} \mathrm{P}-\mathrm{NMR}$ analysis. The freeze-drying method has the risk to cause the loss of some organic P compounds because a considerable amount of freeze-dried powders could not be re-dissolved [32].

The lyophilized $\mathrm{NaOH} / \mathrm{EDTA}$ extracts $(0.3 \mathrm{~g})$ were re-dissolved in $0.6 \mathrm{~mL} \mathrm{D}_{2} \mathrm{O}$ and $0.1 \mathrm{~mL} 10 \mathrm{M} \mathrm{NaOH}$ and then subjected to ultrasonication for $30 \mathrm{~min}$, after which they were allowed to equilibrate for $5 \mathrm{~min}$. The supernatants were subsequently centrifuged for $15 \mathrm{~min}$ at $14000 \mathrm{rpm}$ and then transferred to 5-mm NMR tubes. Solution ${ }^{31} \mathrm{P}-\mathrm{NMR}$ spectra were obtained using a Bruker $400 \mathrm{MHz}$ spectrometer (Bruker, Billerica, MA, USA) at $129.53 \mathrm{MHz}$ with a $90^{\circ} \mathrm{C}$ observation pulse, relaxation delay of $2 \mathrm{~s}$ and acquisition time of $0.6 \mathrm{~s}$. Spectra were collected based on around 20000 scans (Beijing NMR Center) and chemical shifts were recorded relative to $85 \% \mathrm{H}_{3} \mathrm{PO}_{4}$ standard $(\delta=0 \mathrm{ppm})$. Signals were assigned to $\mathrm{P}$ species based on data in previous reports [12, $33,34]$. The peak area was calculated by visual inspection and an automated peak analysis tool. The form of different $\mathrm{P}$ species areas and contribution of the each $\mathrm{P}$ compound group orthophosphate (ortho-P: 6 to $7 \mathrm{ppm}$ ), phosphonates (phon-P: 18 to $20 \mathrm{ppm}$ ), pyrophosphate (pyro-P: -3.5 to $-4.5 \mathrm{ppm}$ ), ortho-phosphate monoesters (mono-P: 4 to $6 \mathrm{ppm}$ ), DNA (DNA-P: 0 ppm), and in the $\mathrm{NaOH} / \mathrm{EDTA}$ extract.

\section{Results}

\subsection{Phosphorus variation in sediment and water}

The TP in surface sediments of the Chaohu Lake displayed a marked variability between the western and eastern lake, with higher concentrations being observed in the western lake. However, the percentage of $\mathrm{P}_{\mathrm{o}}$ showed opposite trends in the sediments $(p<0.01)$ (Tab. 1). Among the ten sediment samples, TP varied greatly from 420.36 to $1089.82 \mathrm{mg} / \mathrm{kg}$, with an average of $686.93 \mathrm{mg} / \mathrm{kg}$. Additionally, the highest TP values were observed in the sediment of the western lake, which was algal-dominated region. The concentration of $\mathrm{P}_{\mathrm{o}}$ in the sediment ranged from 149.60 to $226.68 \mathrm{mg} / \mathrm{kg}$, accounting for 20.56 to $36.69 \%$ of the TP. Moreover, TP in the water column ranged from 0.031 to $0.145 \mathrm{mg} / \mathrm{L}$, with the highest value being observed in the algaldominated western lake. TP in the $\mathrm{NaOH} / \mathrm{EDTA}$ extract ranged from 173.13 to $844.20 \mathrm{mg} / \mathrm{kg}$, accounting for 31 to $77 \%$ of TP in the sediment. $P_{i}$ in extracts ranged from 117.86 to $679.41 \mathrm{mg} / \mathrm{kg}$, while $P_{o}$ in extracts ranged from 55.27 to $164.79 \mathrm{mg} / \mathrm{kg}$ and $\mathrm{P}_{\mathrm{o}}$ recovery by the $\mathrm{NaOH} / \mathrm{EDTA}$ extractions ranged from 30 to $73 \%$. phospholipids (lipids-P: $1-3 \mathrm{ppm}$ ) was calculated relative to the $\mathrm{P}_{\mathrm{o}}$

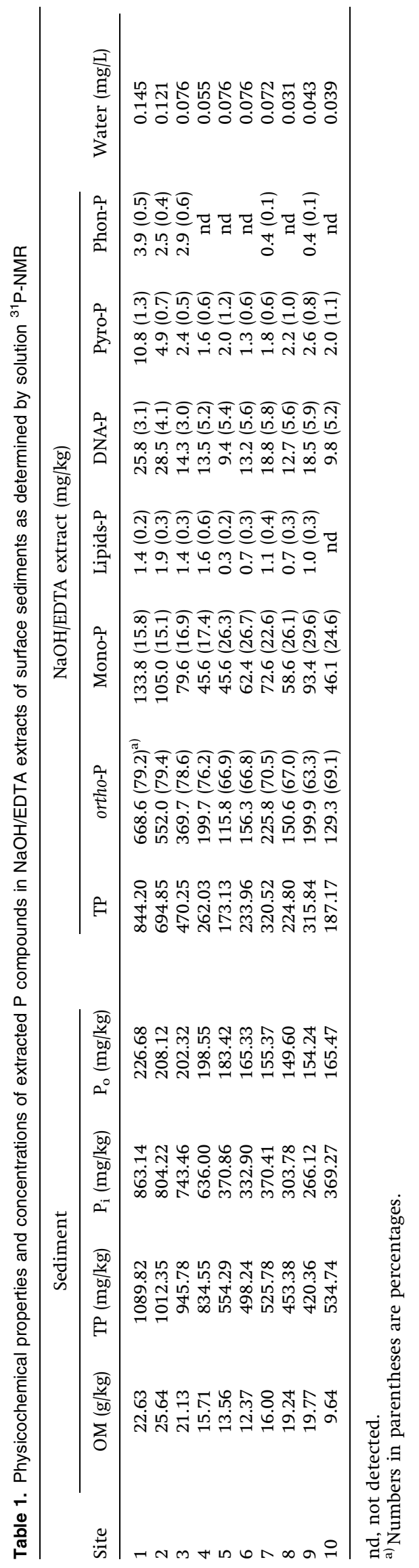


The average concentration of $\mathrm{P}_{\mathrm{o}}$ in the western lake $(208.92 \mathrm{mg} / \mathrm{kg})$ was higher than that in the eastern lake $(162.24 \mathrm{mg} / \mathrm{kg})$, but the ratio of $\mathrm{P}_{\mathrm{o}}$ and TP in the western lake $(21.64 \%)$ was lower than that in the eastern lake (32.74\%). The concentrations of OM varied with those of TP. The contents of OM in the western lake were higher than those in the eastern lake, as indicated by averages of 21.28 and $15.10 \mathrm{~g} / \mathrm{kg}$, respectively.

\section{2 ${ }^{31} \mathrm{P}$-NMR spectra of NaOH/EDTA extracts of surface sediments}

The NMR spectra of the surface lake sediments are shown in Fig. 2 and Tab. 1. Six and five ${ }^{31} \mathrm{P}-\mathrm{NMR}$ compounds were observed in the $\mathrm{NaOH} / \mathrm{EDTA}$ extracts of the western and eastern lake surface sediments, respectively. The concentrations of $\mathrm{P}_{\mathrm{o}}$ differed between the western and eastern lake sediments, and mono-P was the main component of $\mathrm{P}_{\mathrm{o}}$. All NMR spectra showed compounds in the area of phon-P, ortho-P, mono-P, lipids-P, DNA-P, and pyro-P. The concentrations of various $\mathrm{P}$ compound groups in surface sediment are presented in Tab. 1. The concentration of ortho-P ranged from 115.8 to $668.6 \mathrm{mg} / \mathrm{kg}$, accounting for 63.3 to $79.4 \%$ of TP. Mono-P ranged from 45.6 to $133.8 \mathrm{mg} / \mathrm{kg}$, accounting for 15.1 to $29.6 \%$ of TP. Lipids-P ranged from 0 to $1.9 \mathrm{mg} / \mathrm{kg}$, accounting for 0 to $0.6 \%$ of the TP. DNA-P ranged from 9.4 to $28.5 \mathrm{mg} / \mathrm{kg}$, accounting for 3.1 to $5.9 \%$ of the TP. Pyro-P ranged from 1.3 to $10.8 \mathrm{mg} / \mathrm{kg}$, accounting for 0.5 to $1.3 \%$ of the TP. The levels of phon-P ranged from 2.5 to $3.9 \mathrm{mg} / \mathrm{kg}$, accounting for 0.4 to $0.6 \%$ of TP. In surface sediments, mono-P was the main component of $\mathrm{P}_{\mathrm{o}}$ of the TP. Phon-P was primarily found in sediments of the western lake, which were highly polluted. $\mathrm{P}_{\mathrm{o}}$ species and concentrations in the sediments of the western and eastern lake were also affected by the different statuses of lake eutrophication.

\section{3 ${ }^{31} \mathrm{P}$-NMR spectra of NaOH/EDTA extracts of the sediments cores}

To identify and quantify P species and elucidate their transformation process, we analyzed sediment cores by ${ }^{31} \mathrm{P}-\mathrm{NMR}$. A total of six and five $\mathrm{P}$ components in the sediment cores were detected by ${ }^{31} \mathrm{P}-\mathrm{NMR}$ in the western and eastern lake, respectively (Fig. 3 and Tab. 2), including phon-P, ortho-P, mono-P, lipids-P, DNA-P, and pyro-P. As the sediment depth increased $(0-30 \mathrm{~cm})$, the concentrations of TP decreased from 1089.8 to $265.0 \mathrm{mg} / \mathrm{kg}$ and 453.4 to $267.6 \mathrm{mg} / \mathrm{kg}$ in the western and eastern lake, respectively. The ratio of $\mathrm{P}_{\mathrm{o}}$ to TP also decreased from 20.8 to $11.5 \%$ and 33.0 to $8.0 \%$ with increasing depth in the western and eastern lake, respectively. Phon$\mathrm{P}$ was only found in western lake sediment cores, with low levels being observed in the surface sediment and increasing to $10.4 \mathrm{mg} / \mathrm{kg}$ at $10 \mathrm{~cm}$.

As sediment core depth increased, the species and concentration of $\mathrm{P}$ decreased, with a greater decrease being observed in western lake sediment than eastern lake sediment. In western sediment cores, the ortho-P concentration declined from 668.6 to $106.4 \mathrm{mg} / \mathrm{kg}$, while the mono-P concentration decreased from 133.8 to $13.5 \mathrm{mg} / \mathrm{kg}$. Moreover, the diesters $\mathrm{P}$ concentration declined from 29.1 to $0 \mathrm{mg} / \mathrm{kg}$. The pyro-P concentration declined from 10.8 to $0.4 \mathrm{mg} / \mathrm{kg}$. Lipids-P and DNA-P were not detected below 8 and $10 \mathrm{~cm}$, respectively. In sediment cores from the east lake, the ortho-P concentration declined from 150.6 to $147.2 \mathrm{mg} / \mathrm{kg}$, while the mono-P concentration decreased from 58.6 to $12.6 \mathrm{mg} / \mathrm{kg}$. Additionally, diesters $\mathrm{P}$ decreased (from 13.4 to $2.0 \mathrm{mg} / \mathrm{kg}$ ) with increasing sediment depth and was not detected below $14 \mathrm{~cm}$. Pyro-P concentration declined from 2.2 to $0.2 \mathrm{mg} / \mathrm{kg}$.

\section{Discussion}

\section{1 $\mathrm{P}$ forms identified by ${ }^{31} \mathrm{P}-\mathrm{NMR}$}

Mono-P is an important $\mathrm{P}_{\mathrm{o}}$ compound in sediments that includes inositol $\mathrm{P}$, sugar phosphates, and mononucleotides. Inositol phosphates are considered to be the most abundant $\mathrm{P}_{\mathrm{o}}$ in aquatic sediment, which could be mineralized under anaerobic or aerobic conditions [35]. In this study, mono-P comprised $73.2-80.6 \%$ of $\mathrm{P}_{\mathrm{o}}$ in the sediment, being the majority of $\mathrm{P}_{\mathrm{o}}$ in the sediment. Diesters $\mathrm{P}$ is a mixture of numerous compounds with varying lability [36]. In this study, DNA-P and lipids-P were detected in the surface sediment.

Table 2. Concentrations of $\mathrm{P}$ compounds in $\mathrm{NaOH} / \mathrm{EDTA}$ extracts of the sediment cores determined by solution ${ }^{31} \mathrm{P}-\mathrm{NMR}$ (mg/kg)

\begin{tabular}{|c|c|c|c|c|c|c|c|c|c|}
\hline $\begin{array}{l}\text { Sampling } \\
\text { site }\end{array}$ & $\begin{array}{l}\text { Depth } \\
(\mathrm{cm})\end{array}$ & $\begin{array}{c}\mathrm{TP} \text { in } \\
\text { sediments }\end{array}$ & $\begin{array}{c}\mathrm{TP} \text { in } \\
\text { extractions }\end{array}$ & ortho-P & Pyro-P & Mono-P & Lipids-P & DNA-P & Phon-P \\
\hline \multirow[t]{8}{*}{ Core 1} & $0-2$ & 1089.8 & 844.2 & $668.6(79.2)^{\mathrm{a})}$ & $10.8(1.3)$ & $133.8(15.8)$ & $1.4(0.2)$ & $25.8(3.1)$ & $3.9(0.5)$ \\
\hline & $2-4$ & 1201.3 & 757.4 & $613.3(81.0)$ & $5.4(0.7)$ & $106.2(14.0)$ & $1.3(0.2)$ & $26.6(3.5)$ & $4.7(0.6)$ \\
\hline & $4-6$ & 1169.7 & 876.6 & $731.3(83.4)$ & $5.0(0.6)$ & $111.8(12.8)$ & $0.9(0.1)$ & $21.2(2.4)$ & $6.4(0.7)$ \\
\hline & $6-8$ & 1056.8 & 911.2 & 795.3 (87.3) & $3.3(0.4)$ & $84.4(9.3)$ & $1.5(0.2)$ & $14.7(1.6)$ & 12.1 (1.3) \\
\hline & $8-10$ & 1004.2 & 762.8 & 659.9 (86.5) & $2.4(0.3)$ & $79.2(10.4)$ & nd & $10.8(1.4)$ & $10.4(1.4)$ \\
\hline & $16-18$ & 745.5 & 212.4 & $196.2(92.4)$ & $0.1(0.1)$ & $15.5(7.3)$ & nd & $0.6(0.3)$ & nd \\
\hline & $20-22$ & 554.7 & 176.2 & $161.7(91.8)$ & $0.3(0.2)$ & $14.2(8.0)$ & nd & nd & nd \\
\hline & $28-30$ & 265.0 & 120.2 & $106.4(88.5)$ & $0.4(0.3)$ & 13.5 (11.2) & nd & nd & nd \\
\hline \multirow[t]{9}{*}{ Core 8} & $0-2$ & 453.4 & 224.80 & $150.6(67.0)$ & $2.2(1.0)$ & $58.6(26.1)$ & $0.7(0.3)$ & $12.7(5.6)$ & nd \\
\hline & $2-4$ & 469.3 & 269.00 & $184.1(68.4)$ & $2.1(0.8)$ & $69.3(25.8)$ & $0.8(0.3)$ & $12.7(4.7)$ & nd \\
\hline & $4-6$ & 459.1 & 291.60 & $200.3(68.7)$ & $2.0(0.7)$ & $75.2(25.8)$ & $0.8(0.3)$ & $13.2(4.5)$ & nd \\
\hline & $6-8$ & 463.8 & 289.03 & $211.1(73.0)$ & $1.6(0.5)$ & 63.3 (21.9) & $0.7(0.2)$ & $12.3(4.3)$ & nd \\
\hline & $8-10$ & 432.1 & 280.40 & $216.6(77.3)$ & $1.3(0.5)$ & 53.9 (19.2) & $0.8(0.3)$ & $7.8(2.8)$ & nd \\
\hline & $12-14$ & 431.7 & 163.44 & $131.9(80.6)$ & $0.5(0.3)$ & $29.2(17.8)$ & $0.4(0.3)$ & $1.6(1.0)$ & nd \\
\hline & $16-18$ & 321.6 & 155.22 & $130.1(83.8)$ & $0.3(0.2)$ & $24.8(16.0)$ & nd & nd & nd \\
\hline & $20-22$ & 295.0 & 138.60 & $121.2(87.4)$ & $0.4(0.3)$ & 17.1 (12.3) & nd & nd & nd \\
\hline & $28-30$ & 267.6 & 159.91 & $147.2(92.0)$ & $0.2(0.1)$ & $12.6(7.8)$ & nd & nd & nd \\
\hline
\end{tabular}

nd, not detected.

a) Numbers in parentheses are percentages. 


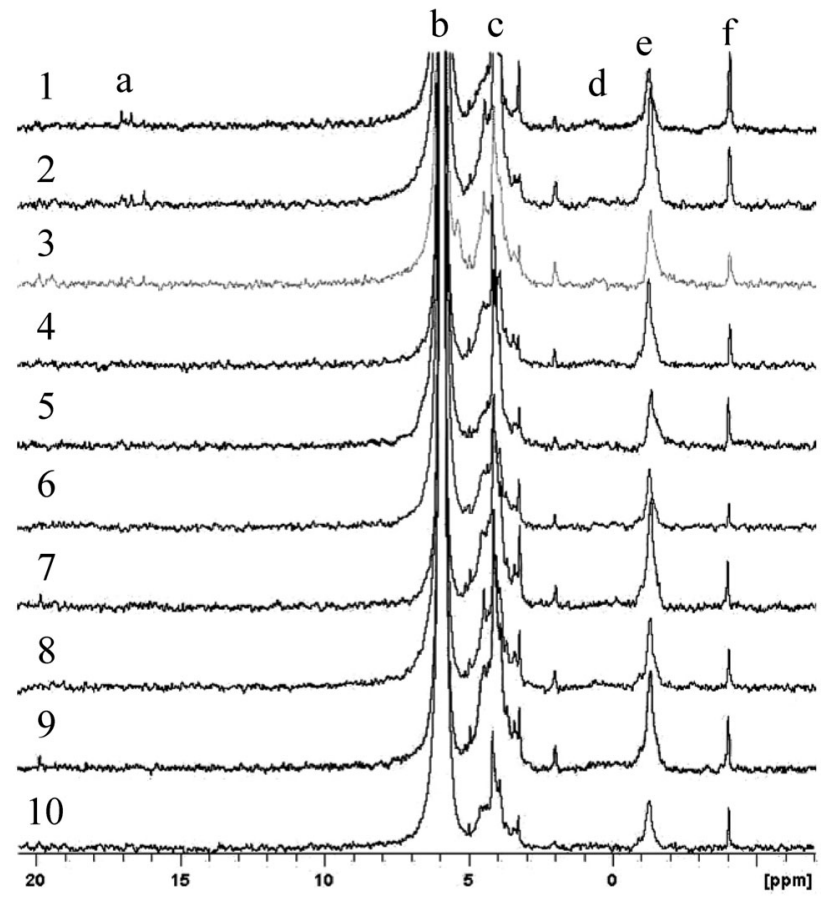

Figure 2. ${ }^{31} \mathrm{P}-\mathrm{NMR}$ spectra of $\mathrm{NaOH} / \mathrm{EDTA}$ extracts of surface sediments in the Chaohu Lake (a: phosphonates; b: ortho-phosphate; c: orthophosphate monoesters; d: phospholipids; e: DNA; f: pyrophosphate).

DNA-P primarily originates from bacteria and hydrophytes [37]. The Chaohu Lake is a shallow and eutrophic lake, where the algaederived organic matter source and high productivity may be the main sources of DNA-P [38, 39]. The amount of pyro-P was less than that of DNA-P. Some studies have suggested that pyro-P may originate from poly-P and esters, which could be hydrolyzed during alkaline extraction [40]. Pyro-P can be directly utilized by aquatic organisms [41]. This study found phon-P in the western lake surface sediment, which is similar to the results of studies of the eutrophic Taihu Lake and Hongfeng Lake [24, 42].

Biogenic $\mathrm{P}$ (phon-P, mono-P, diesters $\mathrm{P}$, and pyro-P) generally decreased as sediment depth increased. When combined with the loss of TP to the water and sediment (Tab. 2) [43], these findings might reflect degradation processes over time as well as loss of sediment $\mathrm{P}$ to the overlaying water column, and also the biogenic $\mathrm{P}$ species would increase immobilization phosphorus by the sediment solids [44, 45]. Reitzel et al. [46] reported that half-lives of the $\mathrm{P}$ species in Lake Erken were as follows: mono-P (29 years) $>$ DNA-P (22 years $)>$ TP $\quad$ (six years) $>$ poly-P (two years) $>$ ortho-P (one year). Ahlgren et al. [47] reported half-lives of mono-P, diesters $P$, and pyro-P of 23 years, 21 years, and 13 years, respectively, in the same lake. In the present study, the most labile $\mathrm{P}$ species was lipids-P, which was found in the top $5 \mathrm{~cm}$ of sediment, and mono-P, DNA-P, and pyro-P, which were mostly common in the top $10 \mathrm{~cm}$ of sediment. The result in this research was similar with the Taihu Lake, which was also a shallow lake. Ding et al. $[44,45]$ reported that half-life of the $\mathrm{P}_{\mathrm{o}}$ compound varied from 3 to 27 years in Taihu Lakes, and the following order was mono- $\mathrm{P}>$ lipids- $\mathrm{P}>\mathrm{DNA}>$ pyro-P. The Chaohu Lake is a shallow lake with an average depth of only $3 \mathrm{~m}$. The lake was heavily used by the shipping and fishery industries; therefore, the surface is subject to disturbance that will affect the water-sediment interface and change the redox conditions or microbial populations. These disturbances will influence the transformation rate of mono-P, DNA-P, and pyro-P. Liable forms of $\mathrm{P}_{\mathrm{o}}$ such as DNA-P and lipids-P mineralize to ortho-P or are utilized by aquatic organisms directly. Accordingly, $\mathrm{P}_{\mathrm{o}}$ in the sediments may be available for recycling to the surface water and supporting the growth of phytoplankton.

\subsection{P species and lake eutrophication}

The concentrations of TP and $\mathrm{P}_{\mathrm{o}}$ in the sediment of the western lake were higher than those in the eastern lake. Specifically, the levels of ortho-P were 78.4 and $67.3 \%$ in the western and eastern lake, respectively. The main reason for this distribution was differences in drainage and pollution sources [27,48]. The industrial and municipal wastewater, and urban non-point source was discharged into the western region of the lake and the non-point source pollution of agriculture was primary in eastern lake region [22]. It is important to note that algal blooms produce organic materials, including abundant $\mathrm{P}_{\mathrm{o}}$, but that the level of ortho-P in eutrophic lake sediments is higher than in mesotrophic sediments, indicating that the rate of organic matter mineralization in eutrophic lakes is faster than in mesotrophic lakes. The positive relationship between total $\mathrm{P}_{\mathrm{o}}$ in sediment and $\mathrm{TP}$ in the water column $\left(\mathrm{R}_{[\text {Po(sediment) }-\mathrm{TP} \text { (water)] }}=0.81, p<0.01\right)$ indicates that $P_{o}$ in the sediment may be released into the water, and may be the $P_{o}$ was origin from the increased input and accumulation of organic matter in surface sediments through the surface water $[38,44]$. Mono- $\mathrm{P}\left(\mathrm{R}_{[\text {mono- } \mathrm{P}(\text { sediment })-\mathrm{TP}(\text { water })]}=0.77\right.$, $p<0.01)$ and pyro-P $\left(\mathrm{R}_{\text {[pyro-P (sediment) }-\mathrm{TP}(\text { water })]}=0.76, p<0.01\right)$ were positively related with TP in the water column. Mono-P is more stable than diesters $\mathrm{P}$, and that is a wide range important $\mathrm{P}_{\mathrm{o}}$ in the sediment, such as inositol hexaphosphoric acid, which can be combined with multivalent ions to form precipitate, but studies have reported that it can be mineralized into $\mathrm{P}_{\mathrm{i}}$ under anaerobic conditions [49]. Pryo-P was the labile $\mathrm{P}_{\mathrm{o}}$ in the sediment, with a short half-life time (three years in Taihu Lake) [45]. As a $\mathrm{P}_{\mathrm{i}}$, the pyro-P will be utilized by the aquatic organism. No correlations were found with TP in the water for the DNA and lipids-P in the sediment. The half-life time of DNA-P was twelve years in Taihu Lake [45], which may be similar with the Chaohu Lake because of the same condition in the two lakes. So we deduced that the DNA-P in the surface sediment may be buried before mineralization [24]. Although lipids$\mathrm{P}$ has long half-life (14 years in Taihu Lake) [45], lipids-P will loss in the alkaline extraction because of hydrolysis or precipitation under strongly alkaline condition [24].

\section{Conclusions}

In this study, the concentration and compounds of $\mathrm{P}_{\mathrm{o}}$ and $\mathrm{P}$ recycling in shallow and eutrophic lakes were determined by ${ }^{31} \mathrm{P}$ NMR. Six P compounds were detected in the sediments, with ortho-P and mono-P being the dominant forms in the surface sediments. As sediment core depths increased, the compounds and concentration of P decreased. Phon-P, lipids-P, DNA-P, and pyro-P were primarily found in the top $10 \mathrm{~cm}$ of sediments. Analysis of the relationships between $\mathrm{P}$ compounds and water quality indicated that the $\mathrm{P}$ recycling rate and mineralization rate of $\mathrm{P}_{\mathrm{o}}$ were faster in eutrophic lakes than that in mesotrophic lakes. Overall, the results demonstrate that compounds, distribution and transformation process are complex in the sediment of eutrophic lakes. 

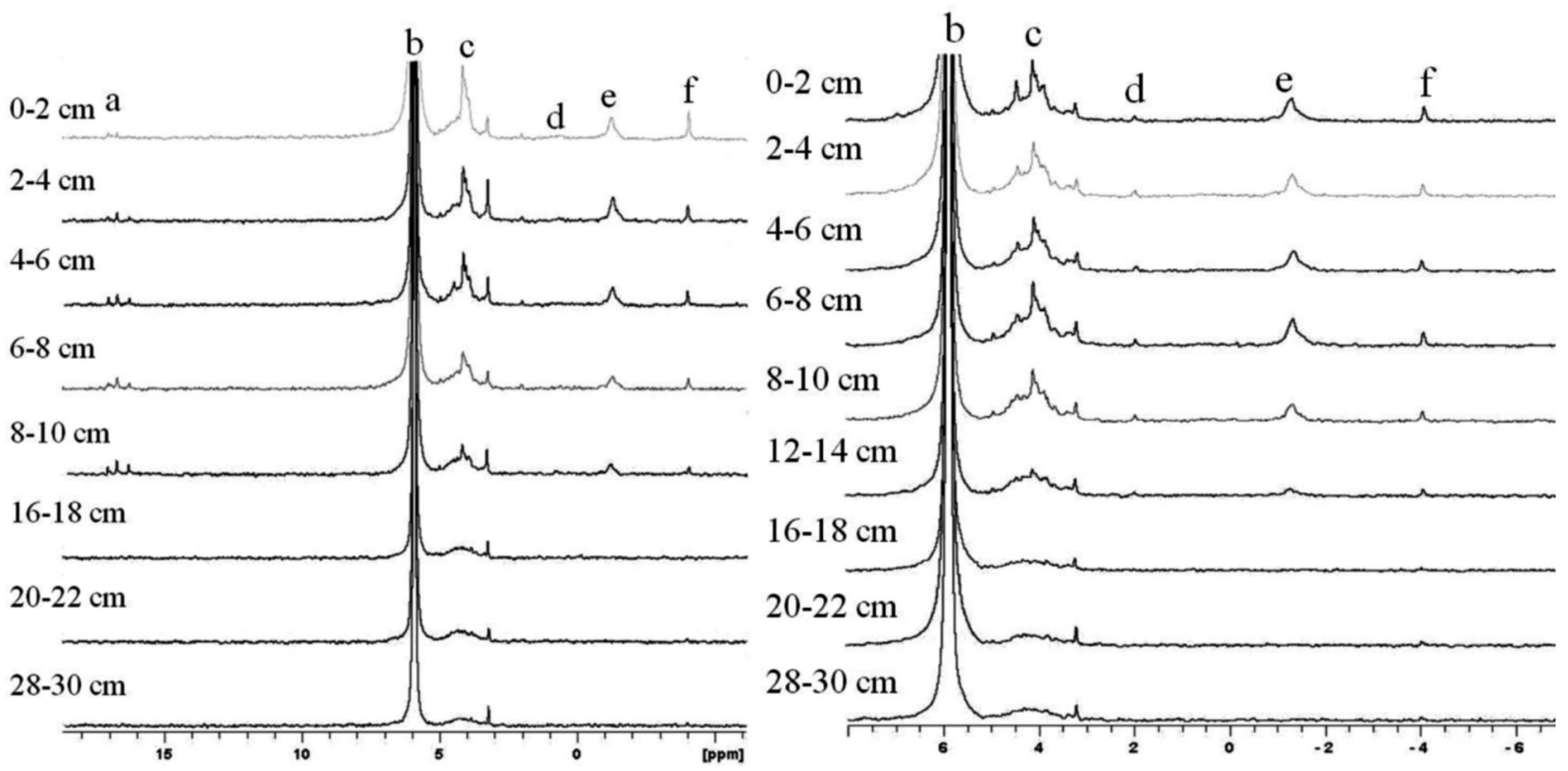

Figure 3. ${ }^{31} \mathrm{P}-\mathrm{NMR}$ spectra of $\mathrm{NaOH} / \mathrm{EDTA}$ extracts of the sediments cores in the Chaohu Lake (a: phosphonates; b: ortho-phosphate; c: orthophosphate monoesters; d: phospholipids; e: DNA; f: pyrophosphate; right: 1, left: 8).

\section{Acknowledgments}

This work was supported by Open Fund of Key Laboratory of Contaminated Environment Control and Regional Ecology Safety (SYU-KF-L-07), Open Fund of Key Laboratory of Regional Environment Eco-remediation, Education Ministry (SYU-KF-E-07), and the National Natural Scientific Foundation of China (21107126 and 20907067).

The authors have declared no conflict of interest.

\section{References}

[1] L. Q. Xie, P. Xie, H. J. Tang, Enhancement of Dissolved Phosphorus Release from Sediment in a Hype-eutrophic, Subtrophical Chinese Lake, Environ. Pollut. 2003, 122, 391-399.

[2] T. Murphy, A. Lawson, M. Kumagai, C. Nalewajko, Release of Phosphorus from Sediments in Lake Biwa, Limnology 2001, 2, 119-128.

[3] P. R. Hesse, Phosphorus Fixation in Mangrove Swamp Muds, Nature 1962, 193, 295-296.

[4] D. J. D'Angelo, J. R. Webster, Phosphorus Retention in Stream Draining Pine and Hardwood Catchments in the Southern Appalachian Mountains, Freshwater Biol. 1991, 26, 335-345.

[5] L. E. Sommers, R. F. Harris, J. D. H. Williams, D. E. Armstrong, J. K. Syers, Fractionation of Organic Phosphorus in Lakes Sediments, Soil Sci. Soc. Am. J. 1972, 36, 51-54.

[6] J. B. Cotner, R. G. Wetzel, Uptake of Dissolved Inorganic and Organic Phosphorus Compounds by Phytoplankton and Bacterioplankton, Limnol. Oceanogr. 1992, 37, 232-243.

[7] M.Suzumura,A.Kamatani, Mineralization of Inositol Hexaphosphate in Aerobic and Anaerobic Marine Sediments: Implications for the Phosphorus Cycle, Geochim. Cosmochim. Acta 1995, 59 (5), 1021-1026.

[8] K. M. Bjorkman, D. M. Karl, Bioavailability of Dissolved Organic Phosphorus in the Euphotic Zone at Station ALOHA, North Pacific Subtropical Gyre, Limnol. Oceanogr. 2003, 48, 1049-1057.

[9] C. R. Benitez-Nelson, K. O. Buesseler, Variability of Inorganic and Organic Phosphorus Turnover Rates in the Coastal Ocean, Nature 1999, 398 (8), 502-505.
[10] S. T. Dyhrman, P. D. Chappell, S. T. Haley, J. W. Moffett, E. D. Orchard, J. B. Waterbury, E. A. Webb, Phosphonate Utilization by the Globally Important Marine Diazotroph Trichodesmium, Nature 2006, 439, 6871.

[11] H. L. Golterman, Fractionation of Sediment Phosphate with Chelating Compounds: A Simplification, and Comparison with Other Methods, Hydrobiologia 1996, 335, 87-95.

[12] B. J. Cade-Menun, Characterizing Phosphorus in Environmental and Agricultural Samples by ${ }^{31} \mathrm{P}$ Nuclear Magnetic Resonance Spectroscopy, Talanta 2005, 66, 359-371.

[13] B. L. Turner, B. J. Cade-Menun, L. M. Condron, S. Newman, Extraction of Soil Organic Phosphorus, Talanta 2005, 66, 294-306.

[14] K. I. Aspila, H. Agemian, A. S. Y. Chau, A Semi-automated Method for the Determination of Inorganic Organic and Total Phosphate in Sediments, Analyst 1976, 101, 187-197.

[15] R. A. Bowman, C. V. Cole, An Exploratory Method for Fractionation of Organic Phosphorus from Grassland Soils, Soil Sci. 1978, 125, 95-101.

[16] G. M. Pierzynski, Methods of Phosphorus Analysis for Soils, Sediments, Residuals, and Waters, Southern Cooperative Series Bulletin No. 396, SERA-IEG, North Carolina State University, Raleigh, NC 2004.

[17] J. A. Brandes, E. D. Ingall, D. Paterson, Characterization of Minerals and Organic Phosphorus Species in Marine Sediments Using Soft Xray Fluorescence Spectromicroscopy, Mar. Chem. 2007, 103, 250-265.

[18] B. Cade-Menun, C. W. Liu, Solution Phosphorus-31 Nuclear Magnetic Resonance Spectroscopy of Soils from 2005-2013: A Review of Sample Preparation and Experimental Parameters, Soil Sci. Soc. Am. J. 2013, 78, 19-37.

[19] B. J. Cade-Menun, C. R. Benitez-Nelson, P. Pellechia, A. Paytan, Refining ${ }^{31} \mathrm{P}$ Nuclear Magnetic Resonance Spectroscopy for Marine Particulate Samples: Storage Conditions and Extraction Recovery, Mar. Chem. 2005, 97, 293-306.

[20] B. L. Turner, S. Newman, K. R. Reddy, Overestimation of Organic Phosphorus in Wetland Soils by Alkaline Extraction and Molybdate Colorimetry, Environ. Sci. Technol. 2006, 40, 3349-3354.

[21] A. L. Doolette, R. J. Smernik, W. J. Dougherty, Overestimation of the Importance of Phytate in NaOH-EDTA Soil Extracts as Assessed by ${ }^{31} \mathrm{P}$ NMR Analyses, Org Geochem. 2011, 42, 955-964. 
[22] S. L. Huo, F. Y. Zan, B. D. Xi, Q. Q. Li, J. T. Zhang, Phosphorus Fractionation in Different Trophic Sediments of Lakes from Different Regions, China, J. Environ. Monit. 2011, 13, 1088-1095.

[23] L. Gao, J. M. Zhou, H. Yang, J. Chen, Phosphorus Fractions in Sediment Profiles and Their Potential Contributions to Eutrophication in Dianchi Lake, Environ Geol. 2005, 48, 835-844.

[24] X. L. Bai, S. M. Ding, C. X. Fan, T. Liu, D. Shi, L. Zhang, Organic Phosphorus Species in Surface Sediments of a Large Shallow, Eutrophic Lake, Lake Taihu, China, Environ. Pollut. 2009, 157, 25072513.

[25] F. Y. Zan, S. L. Huo, B. D. Xi, Q. Q. Li, H. Q. Liao, J. T. Zhang, Phosphorus Distribution in the Sediments of a Shallow Eutrophic Lake, Lake Chaohu, China, Environ. Earth Sci. 2011, 62, 1643-1653.

[26] H. Yu, B. Xi, J. Jiang, M. Heaphy, H. Wang, D. Li, Environmental Heterogeneity Analysis, Assessment of Trophic State and Source Identification in Chaohu Lake, China, Environ. Sci. Pollut. Res. 2011, 18, 1333-1342.

[27] H. Zhang, B. Q. Shan, Historical Distribution and Partitioning of Phosphorus in Sediments in a Agricultural Watershed in the Yangtze-Huaihe Region, China, Environ. Sci. Technol. 2008, 42, 23282333.

[28] L. Håkanson, M. Jansson, Principles of Lake Sedimentology, Springer, New York 1983, p. 316.

[29] H. S. Jensen, P. Kristensen, E. Jeppesen, A. Skytthe, Iron/Phosphorus Ratio in Surface Sediment as an Indicator of Phosphate Release from Aerobic Sediments in Shallow Lakes, Hydrobiologia 1992, 235/236, 731-743.

[30] J. Murphy, J. P. Riley, A Modified Single Solution Method for the Determination of Phosphate in Natural Waters, Anal. Chim. Acta 1962, 27, 31-36.

[31] B. J. Cade-Menun, C. M. Preston, A Comparison of Soil Extraction Procedures for ${ }^{31}$ P NMR Spectroscopy, Soil Sci. 1996, 161 (11), 770-785.

[32] D. Xu, S. M. Ding, B. Li, F. Jia, X. He, C. S. Zhang, Characterization and Optimization of the Preparation Procedure for Solution P-31 NMR Analysis of Organic Phosphorus in Sediments, J. Soils Sediments 2012, 12, 909-920.

[33] B. L. Turner, N. Mahieu, L. M. Condron, Phosphorus-31 Nuclear Magnetic Resonance Spectral Assignments of Phosphorus Compounds in Soil NaOH-EDTA Extracts, Soil Sci. Soc. Am. J. 2003, 67, 497510.

[34] S. M. Ding, D. Xu, B. Li, C. X. Fan, C. S. Zhang, Improvement of ${ }^{31} \mathrm{P}$ NMR Spectral Resolution by 8-Hydroxyquinoline Precipitation of Paramagnetic Fe and $\mathrm{Mn}$ in Environmental Samples, Environ. Sci. Technol. 2010, 44, 2555-2561.

[35] B. J. Turner, M. J. Papházy, P. M. Haygarth, I. D. Mckelvie, Inositol Phosphoates in the Environment, Philos. Trans. R. Soc. London, Ser. B 2002, 357, 449-469.
[36] B. L. Turner, E. Frossard, D. S. Baldwin, Organic Phosphorus in the Environment, CABI Publishing, Wallingford, UK 2005.

[37] J. Ahlgren, K. Reitzel, L. Tranvik, A. Gogoll, E. Rydin, Degradation of Organic Phosphorus Compounds in Anoxic Baltic Sea Sediments: A ${ }^{31} \mathrm{P}$ Nuclear Magnetic Resonance Study, Limnol. Oceanogr. 2006, 51, 2341-2348.

[38] R. Shinohara, A. Imai, N. Kawasaki, K. Komatsu, A. Kohzu, S. Miura, T. Sano, et al., Biogenic Phosphorus Compounds in Sediment and Suspended Particles in a Shallow Eutrophic Lake: A ${ }^{31} \mathrm{P}$-Nuclear Magnetic Resonance ( ${ }^{31} \mathrm{P}$ NMR) Study, Environ. Sci. Technol. 2012, 46, 10572-10578.

[39] F. Y. Zan, S. L. Huo, B. D. Xi, C. W. Zhu, H. Q. Liao, J. T. Zhang, K. M. Yeager, A 100-year Sedimentary Record of Natural and Anthropogenic Impacts on a Shallow Eutrophic Lake, Lake Chaohu, China, J. Environ. Monit. 2012, 14, 804-816.

[40] M. Hupfer, R. Gachter, H. Ruegger, Polyphosphate in Lake Sediments: ${ }^{31} \mathrm{P}$ NMR Spectroscopy as a Tool for Its Identification, Limnol. Oceanogr. 1995, 40 (3), 610-617.

[41] M. Hupfer, B. Rübe, Origin and Diagenesis of Polyphosphate in Lake Sediments: A ${ }^{31}$ P-NMR study, Limnol. Oceanogr. 2004, 49 (1), 1-10.

[42] R. Y. Zhang, F. C. Wu, Z. Q. He, J. Zhang, B. A. Song, L. H. Jin, Phosphorus Composition in Sediments from Seven Different Trophic Lakes, China: A Phosphorus-31 NMR Study, J. Environ. Qual. 2009, 38, 353-359.

[43] J. Y. Wang, H. K. Pant, Assessment of Potential Spatial-temporal Variations in Phosphorus Distribution and Fractionation in River Bed Sediment, Clean - Soil Air Water 2011, 39 (2), 148-156.

[44] D. Xu, S. M. Ding, B. Li, X. L. Bai, C. X. Fan, C. S. Zhang, Species of Organic Phosphorus in a Sediment Profile of Lake Taihu, I. Chemical Forms and Their Transformation, J. Environ. Sci. 2013, 25 (4), 637-644.

[45] S. M. Ding, D. Xu, X. L. Bai, S. C. Yao, C. X. Fan, C. S. Zhang., Speciation of Organic Phosphorus in a Sediment Profile of Lake Taihu, II. Molecular Species and Their Depth Attenuation, J. Environ. Sci. 2013, 25 (5), 925-932.

[46] K. Reitzel, J. Ahlgren, H. DeBrabandere, M. Waldebäck, A. Gogoll, L. Tranvik, E. Rydin, Degradation Rates of Organic Phosphorus in Lake Sediment, Biogeochemistry 2007, 82, 15-28.

[47] J. Ahlgren, L. Tranvik, A. Gogoll, M. Waldeback, K. Markides, E. Rydin, Sediment Depth Attenuation of Biogenic Phosphorus Compounds Measured by ${ }^{31}$ P NMR, Environ. Sci. Technol. 2005, 39, 867-872.

[48] D. J. Chen, J. Lu, H. L. Wang, Y. N. Shen, M. O. Kimberley, Seasonal Variations of Nitrogen and Phosphorus Retention in an Agricultural Drainage River in East China, Environ. Sci. Pollut. Res. 2010, 17, 312320.

[49] S. Masahiro, K. Akiyoshi, Isolation and Determination of Inositol Hexaphosphate in Sediments from Tokyo Bay, Geochim. Cosmochim. Acta 1993, 57 (10), 2197-2202. 